\title{
Temporal bone imaging
}

A 46-year-old man presented to the Department of Otolaryngology with congenital deafness of unknown cause. With the help of hearing aids (which did not provide any speech understanding in the sound-only condition) and by mastering speech reading, he had learned to speak quite fluently at a school for deaf and hearing-impaired children. Despite these capabilities, he came to seek advice about cochlear implants, as he would like to communicate more conveniently with his family, of whom none had significant hearing loss.

On physical examination, he was completely deaf and had adapted to major vestibular deficits (i.e. bilateral vestibular areflexia). The following CT scan of the petrous bone (Figure 1) and MRI images of the cerebellopontine angle (Figure 2) were obtained.

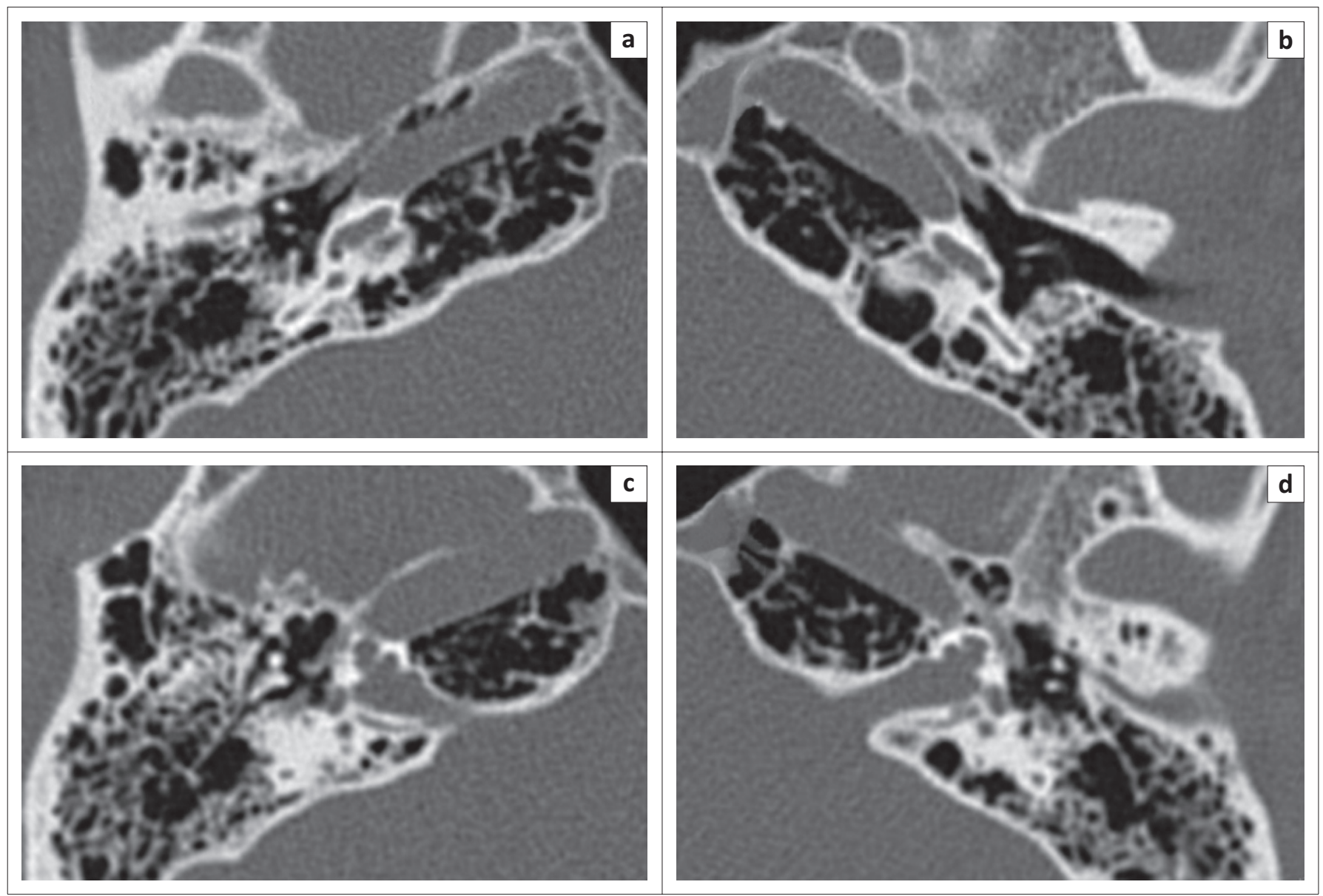

FIGURE 1: Axial images through the right (panel $a, c$, e and $g$ ) and left (panel b, $d, f$ and $h$ ) petrous bone.

\begin{tabular}{ll} 
& $\begin{array}{l}\text { Authors: E.B. Arkink }{ }^{1,2}, \text { J.H.M. Frijns }{ }^{3}, \text { B.M. Verbist }{ }^{1,4} \\
\text { Affiliations: }{ }^{1} \text { Department of Radiology, Leiden University Medical Center, The Netherlands I }{ }^{2} \text { Department of Radiology, } \\
\text { Medical Center Haaglanden, The Netherlands | }{ }^{3} \text { Department of Otorhinolaryngology, Leiden University Medical Center, The }\end{array}$ \\
\hline Read online: & $\begin{array}{l}\text { Netherlands | }{ }^{4} \text { Department of Radiology, Radboud University Nijmegen Medical Center, The Netherlands } \\
\text { Correspondence to: E.B. Arkink }\end{array}$ \\
\hline $\begin{array}{l}\text { Scan this QR } \\
\text { code with your } \\
\text { smart phone or } \\
\text { mobile device } \\
\text { to read online. }\end{array}$ & $\begin{array}{l}\text { Email: e.b.arkink@lumc.nl } \\
\text { Postal address: Albinusdreef 2, 2333 ZA Leiden, Netherlands } \\
\text { How to cite this article: Arkink, E.B., Frijns, J.H.M., Verbist, B.M. Temporal bone imaging. S Afr J Rad. 2015;19(1); Art. \#834, } \\
\text { 2 pages. http://dx.doi.org/10.4102/sajr.v19i1.834 } \\
\text { Copyright: C 2015. The Authors. Licensee: AOSISOpenJournals. This work is licensed under the Creative Commons Attribution License. }\end{array}$
\end{tabular}



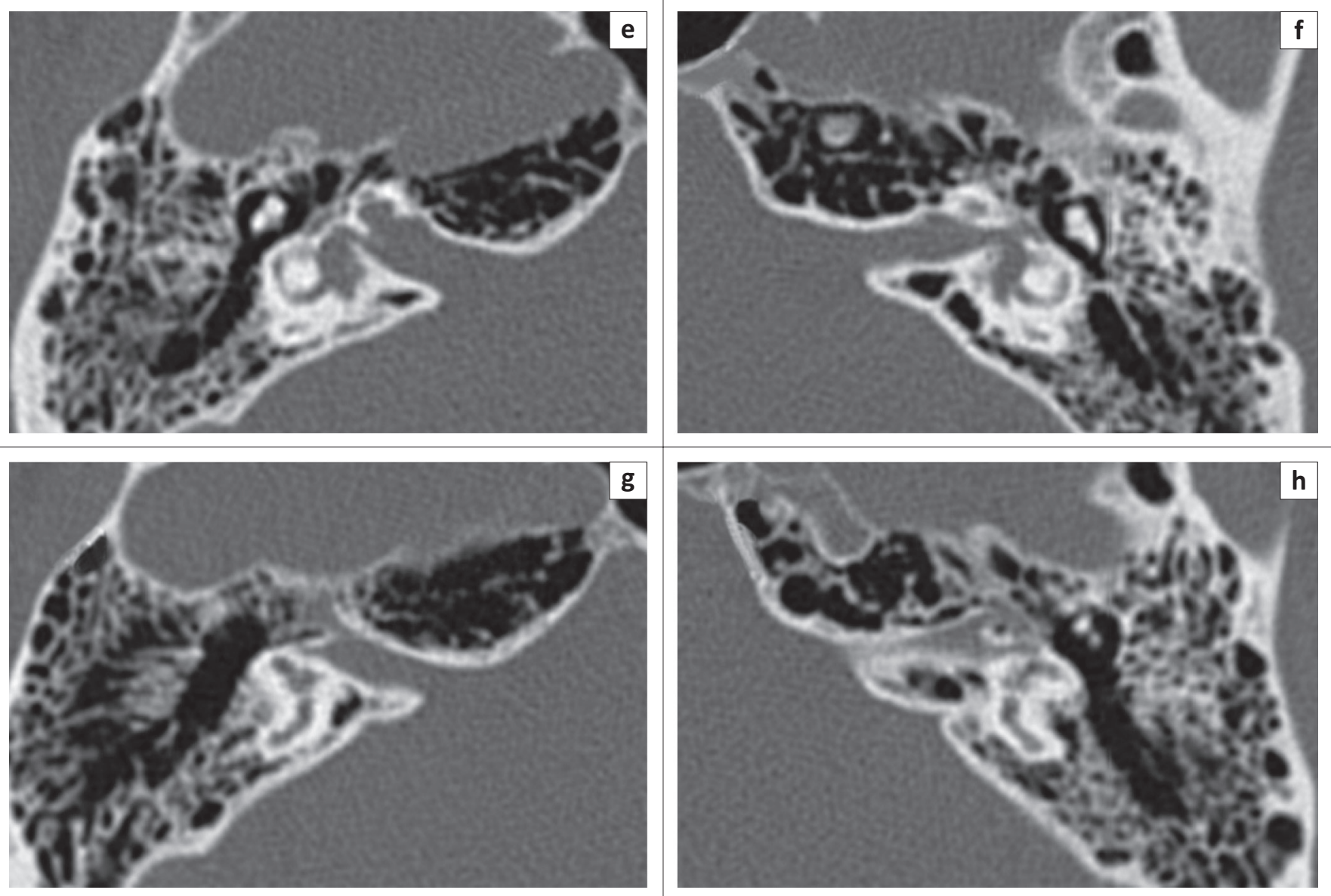

FIGURE 1 (Continues...): Axial images through the right (panel $a, c, e$ and g) and left (panel b, $d, f$ and $h$ ) petrous bone.

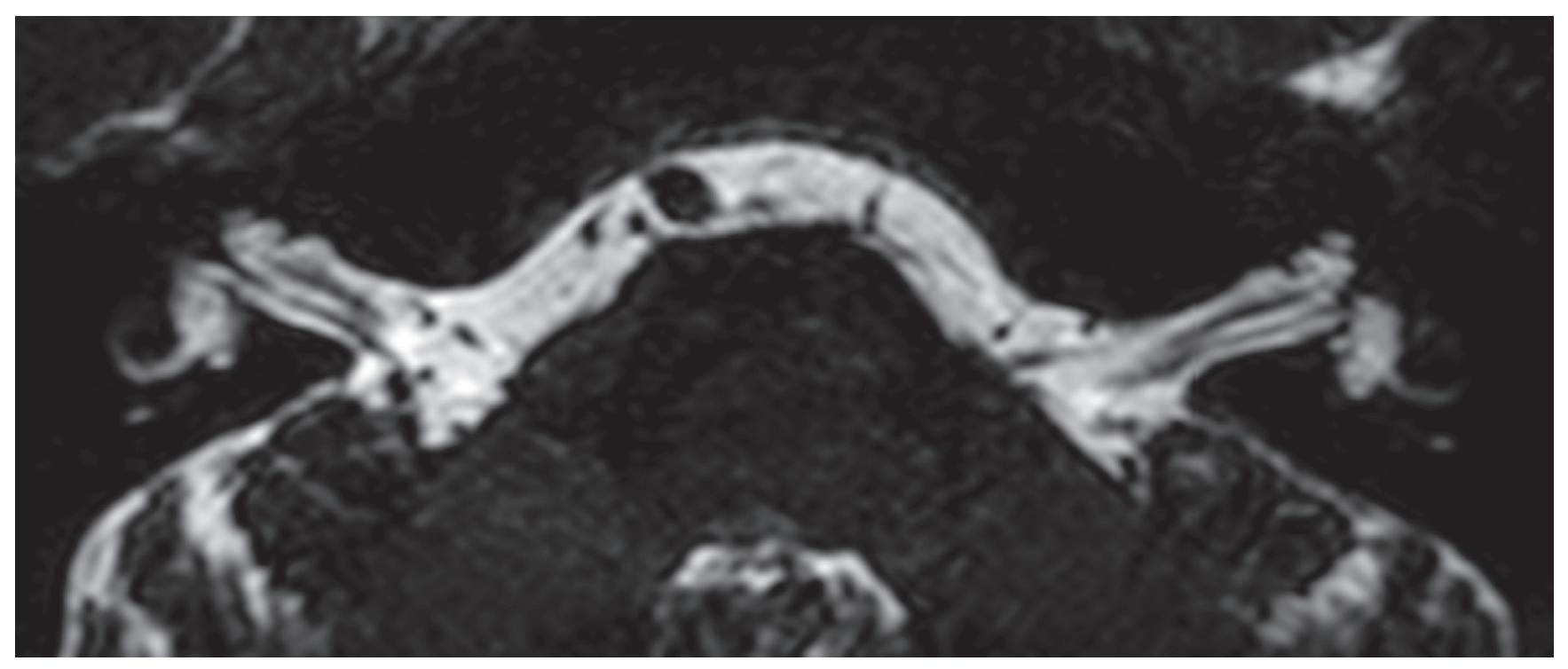

FIGURE 2: Axial T2-weighted MRI of the inner ear, internal auditory canal and cerebellopontine angle.

Describe the relevant imaging findings and formulate the most appropriate clinical diagnosis. Please submit your response to misser@lakesmit.co.za not later than 31 July 2015. The winning respondent will receive R1000 from the RSSA. A detailed diagnosis and discussion will be presented in the next issue of the SAJR. 